\title{
Nilai Pendidikan Agama Hindu Dalam Lontar Swargarohana Parwa
}

\author{
I Nyoman Ariyoga \\ Stah Negeri Mpu Kuturan Singaraja \\ Email: nyomanariyoga92@gmail.com
}

\begin{abstract}
Riwayat Jurnal
Artikel diterima: 21 Juni 2019

Artikel direvisi: 25 Juni 2019

Artikel disetujui: 25 Juni 2019
\end{abstract}

Kata Kunci:

Pendidikan Agama

Hindu,

Lontar Swargarohana

Parwa

\section{Abstrak}

Masyarakat Indonesia khususnya masyarakat Hindu memiliki kearifan lokal tersendiri yang merupakan budaya asli yang telah diturunkan secara turun-temurun. Salah satu kearifan lokal masyarakat Hindu adalah cerita yang terdapat dalam naskah lontar. Ajaran agama Hindu banyak sekali terdapat di dalam naskah-naskah lontar di baik itu berupa Babad, Tantri maupun dalam epos Mahabharata dan Ramayana. Di dalam konsep cerita tersebut banyak sekali terdapat ajaran pendidikan agama hindu yang secara langsung dapat diterapkan dalam menjalani hidup di dunia ini. Dengan demikian penulis tertarik untuk menulis secara lebih luas tentang cerita di Lontar Swargarohana Parwa yang terdapat dalam Mahabharata. Lontar Swargarohana Parwa merupakan parwa kedelapan belas bagian terakhir dalam Mahabharata. Cerita ini berisi tentang Yudistira mencapai surga tapi beliau memilih tinggal di neraka bersama saudara-saudara serta istrinya dari pada tinggal di surga bersama Korawa dan Sekuni, namun beberapa saat kemudian keadaan berbalik yang tadinya neraka menjadi surga begitu juga sebaliknya. Dalam Lontar Swargarohana Parwa terdapat banyak sekali nilai-nilai pendidikan agama Hindu yang terkadung didalamnya sehingga penulisan ini dilaksanakan untuk mengulas Lontar Swargarohana Parwa dilihat dari kajian pendidikan agama Hindu.

\begin{tabular}{|l|l|}
\hline Keyword: & Abstract \\
Hindu & Religious \\
Education, & $\begin{array}{l}\text { The Indonesian people, especially the Hindu community, have } \\
\text { their own local wisdom which is an indigenous culture that has } \\
\text { Lontar Swargarohana } \\
\text { Parwa }\end{array}$ \\
$\begin{array}{l}\text { been passed down through generations. One of the local wisdoms } \\
\text { of the Hindu community is the story found in the lontar text. The } \\
\text { teachings of Hinduism are abundant in lontar texts in the form of } \\
\text { Babad, Tantri and in the epics of the Mahabharata and Ramayana. }\end{array}$ \\
\hline
\end{tabular}




\begin{tabular}{|l|l|}
\hline In the concept of the story there are many teachings of Hinduism \\
education which can directly be applied in living life in this world. \\
Thus the authors are interested in writing more broadly about the \\
stories in Lontar Swargarohana Parwa contained in the \\
Mahabharata. Lontar Swargarohana Parwa is the last eighteenth \\
part of the Mahabharata. This story is about Yudistira reaching \\
heaven, but he chose to live in hell with his brothers and wife \\
instead of living in heaven with the Korawa and Sekuni, but a few \\
moments later the situation turned to hell and vice versa. In Lontar \\
Swargarohana Parwa there are a lot of Hindu religious education \\
values contained in it, so this paper was carried out to review \\
Lontar Swargarohana Parwa viewed from a study of Hindu \\
religious education.
\end{tabular}

\section{Pendahuluan}

Pada perkembangan zaman dewasa ini banyak dijumpai naskah-naskah kesusastraan yang memberikan tuntunan dan petunjuk bagi umat manusia tentang kebenaran dan kebijaksanaan yang mesti di jalankan dalam kehidupan di dunia ini. Semua naskah kesusastraan tersebut merupakan penjabaran dari nilai-nilai yang terkandung di dalam Weda. Naskah kesusastraan tersebut misalnya Ramayana, Mahabarata, Arjuna Wiwaha maupun cerita-cerita rekaan. Nilai-nilai budaya Bali terutama naskah kesusatraan sangat berperan dalam usaha ikut membangun bangsa dan pembentukan manusia Indonesia seutuhnya. Oleh karena itu nilai-nilai budaya daerah Bali terutama naskah kesusastraan merupakan bagian dari budaya nasional perlu untuk dilestarikan, dibina dan dikembangkan agar terhindar dari kepunahan. Nilai-nilai budaya tersebut banyak terdapat dalam naskah-naskah sastra yang tersebar di masyarakat maupun yang sudah terkumpul di lembaga formal. Sebagian besar naskah-naskah itu masih termuat dalam bentuk lontar. Dewasa ini banyak diadakan alih aksara dari beberapa lontar untuk memenuhi beberapa kebutuhan masyarakat atau mahasiswa akan berbagai informasi mengenai kebudayaan Bali yang bersumber dari pustaka Lontar.

Munculnya berbagai macam karya sastra merupakan niat suci dan kewajiban moral bagi para rohaniawan atau para Maha Rsi zaman dahulu untuk mensosialisasikan isi daripada ajaran Weda. Mengingat Weda sangat susah dipahami oleh kebanyakan orang baik tentang huruf maupun bahasanya atas dasar itulah para rohaniawan merasa punya kewajiban untuk mendayagunakan isi kitab suci Weda ke dalam berbagai bentuk karya sastra. Diantaranya karya sastra yang dipandang paling mudah dipahami dan mendorong masyarakat untuk memahami adalah karya sastra dalam bentuk cerita. Salah satu karya sastra monumental adalah 
Mahabarata yang dipandang sebagai Weda kelima hingga kini populer hampir di seluruh belahan dunia bagi penggemar sastra. Isi dari Mahabarata secara keseluruhan mengandung nilai kemanusiaan yang sangat kompleks, baik tentang hakikat Ke-Tuhanan, budaya, alam semesta maupun nilai sosial kemasyarakatan. Mahabarata disusun atas delapan belas parwa yang masing-masing parwa memiliki nuansa dan karakteristik nilai falsafah yang berbeda menyangkut tentang kemanusiaan, alam semseta, dan konsep teologi.

Berlandaskan dengan hal tersebut di atas, maka penulis tertarik untuk mempelajari dan menulis atau memahami sekaligus mengkaji permasalahan ini secara lebih mendalam yaitu menggali Kajian Pendidikan Agama Hindu dalam Lontar Swargarohana Parwa yang sudah barang tentu cerita tersebut terkandung di dalam cerita Mahabharata. Kitab Swargarohana Parwa menceritakan kisah Yudistira yang mencapai puncak gunung Himalaya dan dijemput untuk mencapai surga oleh dewa Indra. Dalam perjalanannya dia ditemani oleh seekor anjing yang sangat setia. Dia menolak masuk sorga jika disuruh untuk meninggalkan anjingnya sendirian. Si anjing menampakkan dirinya yang sebenarnya adalah Dewa Dharma. Di dalam buku ini dikisahkan bagaimana Sang Yudistira yang di angkat naik ke Surga lebih memilih pergi ke neraka daripada tinggal di surga dengan para korawa karena di surga dia tidak menemui saudara-saudaranya, para pandawa dan dewi Drupadi. Maka Yudistirapun berangkat ke neraka dan sesampainya, dia melihat saudara-saudaranya sengsara dan diapun merasa sedih. Tetapi tiba-tiba sorga berubah menjadi neraka dan neraka tempat mereka berada berubah menjadi sorga. Ternyata para pandawa dan Drupadi pernah berdosa sedikit sehingga harus dihukum, sedangkan para korawa pernah berbuat baik sedikit tetapi perbuatan jahatnya jauh lebih banyak sehingga beginilah hukumannya. Kiranya perlu ditegaskan bahwa tulisan ini hanya mengulas Lontar Swargarohana Parwa dilihat dari kajian pendidikan agama Hindu.

\section{Pembahasan}

\section{Nilai-Nilai Pendidikan Dalam Lontar Swargarohana Parwa}

Penelitian ini merupakan penelitian tekstual, yakni menggunakan teks sebagai sumber utama. Hal ini dilakukan semata untuk mengetahui pola pikir dan kronologis pemikiran umat Hindu pada masa silam. Demikian pula, jenis penelitian ini adalah jenis penelitian deskriptif dengan menggunakan pendekatan penelitian kualitatif. Adapun nilai-nilai Pendidikan Agama Hindu yang terkandung didalamnya sebagai berikut: 


\section{Nilai Pendidikan Sosial}

Manusia adalah makhluk sosial yang hidup dan berinteraksi dengan sesamanya. Manusia saling membutuhkan sesamanya baik itu jasmani maupun rohani. Proses interaksi inilah memerlukan nilai-nilai yang merupakan faktor penting dalam hubungan manusia. Nilai-nilai yang dimaksud disini adalah suatu norma-norma yang sifatnya mengatur dan mendidik. Hal ini karena dalam setiap kelompok masyarakat atau dapat dikatakan dimana ada masyarakat atau sekelompok orang yang membentuk suatu hubungan pasti akan terdapat suatu hukum baik itu mengikat maupun tidak. Hukum merupakan nilai-nilai atau norma-norma untuk mengatur antara hubungan sosial manusia. Dapat dikatakan bahwa tiada hubungan sosial tanpa nilai-nilai dan tiada nilai tanpa hubungan sosial (Usman \& Akbar, 1996)

Dengan adanya suatu norma-norma akan terbentuk suatu keteraturan baik itu antara manusia dengan sesamanya maupun dengan lingkungan alam semesta tempat tinggal mereka. Kebenaran, kebaikan, kebajikan, kejujuran, cinta sesama adalah potensi martabat manusia. Kebaikan manusia dapat diukur dengan kenyataan seberapa jauh dia merealisasi potensi martabat manusia itu dalam tingkah lakunya. Martabat dan kepribadian manusia dapat diukur dengan norma-norma yang berlaku dalam arti sejauh mana mereka sudah merealisasikan dan menjalankan nilai-nilai yang sudah berlaku (Muhibbin, 1995, hal. 10). Sadar nilai yang bersumber pada kesadaran sendiri terutama mengerti tujuan hidupnya atau paling tidak ia mengerti untuk apa manusia hidup dengan keterbatasan dan juga segala potensinya. Sesuatu yang ada di alam semesta langsung atau tidak langsung disadari atau tidak oleh manusia adalah mengandung nilai-nilai tertentu karena alam mempunyai nilai bagi kehidupan mansuia. Nilai Pendidikan Sosial yang terdapat dalam Lontar Swargarohana Parwa adalah ketika Yudistira mencari Bima, Arjuna, Nakula, Sahadewa dan Drupadi serta para sekutunya. Yudistira merasa tidak dapat hidup sendiri tanpa ditemani oleh sanak keluarganya. Akhirnya diputuskanlah untuk mencari sanak keluarganya walaupun dimana berada.

Dapat disimpulkan bahwa segala sesuatu yang akan dilakukan tidak bisa dilakukan dengan individu. Seperti cerita di atas Yudistira mencari saudara-saudaranya dan istri serta sekutu Pandawa. Jadi sebagai makhluk sosial segala sesuatunya haruslah dilakukan dengan jalan kerja sama untuk mencapai tujuan yang diinginkan.

\section{Nilai Yadnya}

Ada awalnya banyak orang mengartikan bahwa yadnya semata upacara ritual keagamaan. Pemahaman ini tentu tidak salah karena upacara ritual keagamaan adalah bagian dari yadnya. Pada dasarnya Yadnya bukanlah sekedar upacara keagamaan, lebih dari itu segala aktivitas 
manusia dalam rangka sujud bhakti kepada Hyang Widhi adalah Yadnya. Yadnya berasal dari Bahasa Sansekerta dari akar kata "Yaj" yang artinya memuja. Secara etimologi pengertian Yadnya adalah korban suci secara tulus ikhlas dalam rangka memuja Hyang Widhi. Pada dasarnya Yadnya adalah penyangga dunia dan alam semesta, karena alam dan manusia diciptakan oleh Hyang Widhi melalui Yadnya. Pada masa srsti yaitu penciptaan alam Hyang Widhi dalam kondisi Nirguna Brahma (Tuhan dalam wujud tanpa sifat) melakukan Tapa menjadikan diri beliau Saguna Brahma (Tuhan dalam wujud sifat Purusha dan Pradhana). Dari proses awal ini jelas bahwa awal penciptaan dilakukan Yadnya yaitu pengorbanan diri Hyang Widhi dari Nirguna Brahma menjadi Saguna Brahma. Selanjutnya semua alam diciptakan secara evolusi melalui Yadnya. Bagi manusia relegius keberadaan ritual memang penting dalam kehidupannya melalui upacara manusia religius membangun semangat baru dalam kehidupannya juga menggantungkan sebagai angan dan cita-citannya menuju kehidupan yang lebih baik (Sutrisno, 1997, hal. 234).

Nilai yadnya (korban suci dan keiklasan), bermacam-macam yadnya dijelaskan dalam cerita Swargarohana Parwa, ada yadnya dengan tapa, yoga, yadnya mempelajari kitab suci ,yadnya ilmu pengetahuan, yadnya untuk kebahagiaan sanak keluarga dan istri. Korban suci dan keiklasan yang dilakukan oleh seseorang dengan maksud tidak mementingkan diri sendiri dan menggalang kebahagiaan bersama adalah pelaksanaan ajaran dharma yang tertinggi (yajnam sanatanam). Kegiatan upacara agama dan dharma sadhana lainnya sesungguhnya adalah usaha peningkatan kesucian diri. Kitab suci Manawa Dharmasastra V.109 menyebutkan: "Tubuh dibersihkan dengan air, pikiran disucikan dengan kejujuran (satya), atma disucikan dengan tapa brata, budhi disucikan dengan ilmu pengetahuan (spiritual)"

Nilai yadnya yang terdapat dalam Lontar Swargarohana Parwa adalah yadnya untuk kebahagiaan sanak keluarga dan istri ketika Yudistira menceburkan diri kesungai di neraka yang airnya mendidih. Yang bernama sungai Witarini, Yudistira dengan tulus ikhlas menceburkan dirinya ke dalam sungai demi bisa berkumpul dengan saudara-saudara dan istrinya. Ketika Yudistira menceburkan dirinya kedalam sungai, seketika air yang tadinya mendidih berubah menjadi sejuk.

Dapat disimpulkan bahwa segala sesuatu yang akan dilakukan secara tulus ikhlas akan mendapat hasil seperti yang diharapkan. Seperti cerita di atas Yudistira mencari saudarasaudaranya dan istri serta sekutu Pandawa walaupun harus mengorbankan dirinya sendiri demi bisa berkumpul kembali dengan sanak keluarganya . Jadi segala sesuatunya haruslah dilakukan 
dengan tulus ikhlas dan tanpa ada paksaan maka akan menemukan jalan terbaik untuk mencapai tujuan yang diinginkan.

\section{Nilai Moral}

Dari segi etimologis perkataan moral berasal dari bahasa latin yaitu "Mores" yang berasal dari suku kata "Mos", mores berarti adat istiadat, kelakuan, tabiat, watak, akhlak, yang kemudian artinya berkembang menjadi sebagai kebiasaan dalam bertingkah laku yang baik (susila). Moralitas berarti yang mengenai kesusilaan (kesopanan, sopan-santun, keadaban). Orang yang susila adalah orang yang baik budi bahasanya (Darmadi, 2007, hal. 50).

Dalam buku filsafat Moral, (Poespoprodjo, 1998, hal. 118) menjelaskan bahwa moralitas bahwa moralitas adalah kualitas dalam perbuatan manusia yang menunjukkan bahwa perbuatan itu benar atau salah, baik atau buruk. Dalam Wrhaspati Tattwa juga mengajarkan bahwa kecenderungan sifat manusia itu timbul dari Tri Guna. Dalam ajaran ini Tri Guna adalah bagian dari Citta yaitu pikiran, pikiranlah yang menentukan seseorang akan selamat atau celaka, duka atau bahagia. Hal ini dituangkan demikian :

Moksah svargasca narakam, Tiryaghhavasca manusam, Cittapapayasya jayate Cittayasya hyanubhavatah

Artinya :

Pikiran yang menyebabkan sang pribadi menikamati surga, pikiran yang menyebabkan sang pribadi jatuh ke neraka, pikiran yang menyebabkan menjadi binatang, pikiran yang menyebabkan menjelma menjadi manusia, pikiran yang menyebabkan orang untuk mencapai moksa dan kelepasan sebabnya demikian. (Tim Penyusun, 2010)

Berdasarkan kutipan diatas jelaslah bahwa pikiranlah yang menyebabkan orang selamat atau celaka didalam kehidupannya maupun di akhirat. Seseorang mendapat surga maupun neraka adalah tergantung pengaruh guna dalam dirinya. Kebaikan adalah sesuatu yang diinginkan oleh setiap orang, karena merupakan tujuan hidup. Jadi moral meninjau lapangan terbatas pada sifat yang mempengaruhi manusia. Tri Guna Dalam Nilai Moral. Menurut lontar-lontar yang ada kecenderungan-kecenderungan prilaku seseorang bersumber pada Tri Guna, Tri Guna terdiri dari dua kata yaitu Tri yang artinya tiga dan Guna yang artinya sifat atau perilaku. Jadi Tri Guna yaitu tiga sifat yang dibawa dari sejak lahir. (Penyusun, 2010, hal. 62). Tiga sifat tersebut antara lain adalah: (1) Sattwam berarti sifat-sifat benar, tenang dan suci pada manusia khususnya, atau sifat yang baik pada makhluk hidup umumnya. (2) Rajas atau Hajas berarti sifat aktif dan bersemangat yang merupakan sumber tenaga penggerak untuk dapat mengerjakan sesuatu, sifat ini menyebabkan makhluk itu aktif di dalam kehidupannya. 
(3) Tamas adalah sifat-sifat malas, tamak atau rakus, penuh dengan hawa nafsu yang menyebabkan makhluk-makhluk ada pada kegelapan dan kemalangan yang mengakibatkan dosa lahir dan batin.

Ketiga guna ini akan menguasai dan dimiliki oleh setiap orang, dan akan tampak tercetus pada setiap orang dalam ukuran berbeda-beda. Seseorang yang dipengaruhi oleh guna Sattwam akan menjadi orang yang bijaksana, berpendirian, berfikir tenang, berpandangan luas, tegas dan simpatik serta cenderung pada dharma dan pelaksanaannya akan mencerminkan kesucian. Bila guna rajas mempengaruhi seseorang akan menjadi seseorang yang tangkas, keras, rajin penuh inisiatif serta kreatif. Namun bila guna tamas mempengaruhi manusia akan menjadi orang yang lamban, malas, bodoh. Dari pengaruh ketiga guna ini pada diri manusia maka sikap penampilan seseorang akan terlihat berbeda-beda dan dari sikap berbeda ini lalu orang menggolongkan sikap mana yang disebut baik dan sikap mana yang disebut tidak baik, serta ada penilaian tersendiri. Dari semua hal tersebut di atas adalah merupakan dasar-dasar ajaran yang merupakan laksana kita dalam berlaku susila (Penyusun, 2010, hal. 62). Dalam kitab Wraspati Tattwa sloka 15 dikatakan sebagai berikut :

Laghu prakasakam sattwam cancalam tu rajah sthitamTamo guru varanakam ityetaccinta laksanam Ikang citta mahangan mawa, yeka sattwa ngaranya,Ikang madres molah, yeka rajah ngaranya, ikang abwat Peteng, yeka tamah ngaranya. Artinya :

Pikiran yang ringan dan terang, itu sattwam namanya, yang bergerak cepat, itu rajah namanya, yang gelap serta gelap, itu tamah namanya (Penyusun, 2010, hal. 63)

Sloka diatas gambaran dari tiga sifat yang tidak bisa dipisahkan dari dalam diri manusia, karena hampir setiap manusia memiliki ketiga sifat ini, namun manusia diharapkan agar menjauhi segala sifat-sifat yang dapat merugikan dirinya sendiri maupun orang lain. Berdasarkan pemaparan tersebut di atas dapat ditarik kesimpulan bahwa moral dalam penelitian ini berarti budi pekerti muncul dari dalam diri, merupakan suatu proses yang berkembang bagaimana ia berfikir yang dapat membentuk kepribadian seseorang. Pekerti adalah prilaku yang kemudian mengalir berupa prilaku yang dapat menciptakan, menyenangkan orang, membuat orang merasa aman, dapat bangkitkan orang kusam menjadi cerah,dan sifat keteladanan itulah yang bisa disebut bermoral yang dapat diwujudkan dalam kehidupan sehari-hari seperti rajin sembahyang, tidak suka berbohong dan berlaku adil.

Di dalam Lontar Swargarohana Parwa banyak terdapat konflik-konflik yang memperlihatkan adanya pesan-pesan moral yang dapat dijadikan pelajaran bagi kehidupan 
sebagai manusia yang beragama. Swargarohana Parwa menceritakan tentang perjalanan Yudistira menuju sorga. Yudistira yang mencapai puncak gunung Himalaya dan dijemput untuk mencapai surga oleh Dewa Indra. Dalam perjalanannya dia ditemani oleh seekor anjing yang sangat setia. Dia menolak masuk sorga jika disuruh untuk meninggalkan anjingnya sendirian. Si anjing menampakkan dirinya yang sebenarnya adalah Dewa Dharma. Hal ini mecerminkan sifat baik yang disebut dengan sattwam pada ajaran Tri Guna. Oleh karena itu Yudistira sangat cenderung memiliki sifat sattwam yang dipenuhi oleh sifat kebaikan, olas asih dan cinta kasih yang akan membawanya pada ketenangan dan mengakibatkan bahagia lahir batin.

Nilai moral juga tertuang pada kutipan cerita ketika Yudistira menuju neraka untuk bertemu saudara-saudaranya serta istri dan sekutu Pandawa. Yudistira menceburkan diri ke dalam kobaran api untuk dapat bertemu dengan saudara-saudaranya serta istri dan sekutu Pandawa. Seketika kobaran api itu mengecil dan hilang serta tempat yang tadinya neraka berubah menjadi sorga yang indah berbanding terbalik dengan tempat Duryodana dan para Korawa yang semulanya surga berubah menjadi neraka siksaan. Lalu muncullah Dewa Indra dan Dewa Dharma untuk menjelaskan bahwa lebih banyak dosa ketimbang kebajikan yang diperbuat maka akan menikmati surga terlebih dahulu, baru kemudian dijebloskan ke neraka. Sebaliknya orang yang berbuat kebajikannya ketimbang dosanya akan diberikan siksa neraka terlebih dahulu sebelum diberikan kenikmatan surga.

Berdasarkan pemaparan tersebut diatas, maka sangat jelas bahwa sikap moral yang baik sangat diperlukan dalam menjalani hidup sehari-hari. Nilai moral muncul dari budi pekerti yang ada dari dalam diri, yang merupakan suatu proses yang berkembang bagaimana ia berfikir yang dapat membentuk kepribadian seseorang. Dengan budi pekerti yang luhur maka akan muncul nilai-nilai moral yang akan membawa setiap manusia yang mengamalkannya mendapatkan kehidupan yang indah sesuai dengan tujuan agama Hindu yaitu Moksa.

\section{Nilai Kepemimpinan}

Kepemimpinan adalah kemampuan untuk mempengaruhi suatu kelompok menuju tercapainya tujuan-tujuan (Robbin \& Coulter, 1999). Kepemimpinan dapat diartikan adalah kemampuan seseorang untuk menguasai atau mempengaruhi orang lain atau masyarakat yang saling berbeda-beda menuju kepada pencapaian tertentu. Definisi kepemimpinan ini mengindikasikan bahwa pentingnya sebuah kepemimpinan dalam suatu organisasi agar pencapaian tujuan organisasi dapat terpenuhi. 
Menurut (Hasibuan, 2003), kepemimpinan adalah cara seorang pemimpin mempengaruhi perilaku bawahan, agar mau bekerja sama dan bekerja secara produktif untuk mencapai tujuan organisasi. Kepemimpinan didefinisikan sebagai proses mengarahkan dan mempengaruhi aktivitas yang berkaitan dengan tugas dari para anggota kelompok. Definisi kepemimpinan secara luas meliputi proses mempengaruhi dalam menentukan tujuan organisasi, memotivasi perilaku pengikut untuk mencapai tujuan, mempengaruhi untuk memperbaiki kelompok dan budayanya. Selain itu juga mempengaruhi interpretasi mengenai perisiwa-peristiwa para pengikutnya, pengorganisasian, dan aktivitas-aktivitas untuk mencapai sasaran, memelihara hubungan kerja sama dan kerja kelompok, perolehan dukungan dan kerja sama dari orang-orang di luar kelompok atau organisasi.

Kepemimpinan adalah proses mendorong dan membantu orang lain untuk bekerja secara antusias ke arah tujuan. Kepemimpinan juga berarti aktivitas mempengaruhi orang lain untuk berusaha mencapai tujuan kelompok secara sukarela. Dengan kata lain kepemimpinan adalah proses mempengaruhi orang lain untuk mengerjakan apa yang diinginkan untuk dikerjakan oleh orang lain. Konsep demikian kelihatanya sederhana, tetapi pada kenyataannya sering kali sangat kompleks, karena didalam kepemimpinan hadir suatu proses mengarahkan dan mempengaruhi tugas-tugas yang berhubungan dengan kegiatan antar kelompok. Berdasarkan uraian diatas ada empat implikasi penting, yaitu:

Kepemimpinan merupakan seni untuk mempengaruhi tingkah laku orang, sehingga tergerak untuk mengikuti kemauan dengan ikhlas guna mencapai tujuan bersama.Sedangkan pemimpin adalah seorang Pribadi yang memiliki kemampuan untuk menggerakkan orang lain dalam upaya mencapai tujuan tertentu. Seorang pemimpin hendaknya dapat melaksanakan tugas-tugasnya sesuai kewenangan yang dimiliki. Wewenang seorang pemimpin adalah hak untuk menggerakkan orang atau bawahan agar mau mengikuti kehendak sesuai tugas yang diberikan. Tugas merupakan kwajiban yang harus dilaksanakan. Sukses seorang pemimpin tergantung kepada pemahaman dan pengetahuan serta penerapan teori kepemimpinan. Dalam kitab suci agama Hindu Nitisastra, I,4 disebutkan:

"Ring jan madhika meta citta reseping sarwa praja ngenaka,ring stri madhya manchara priya wuwus tangde manah kung lulut, yen ring madhyani sang pandita mucap tattwa padeca prihen, yen ring madhyanikang musuh mucapaken wak sura singhakreti 
Artinya ;

Orang yang terkemuka (Pemimpin) harus bisa mengambil hati dan menyenangkan hati orang, jika berkumpul dengan wanita harus dapat menimbulkan rasa cinta,jika berkumpul dengan pendeta harus dapat membicarakan ajaran ketatwaan/keagamaan yang baik,dan jika berhadapan dengan musuh harus dapat mengucapkan kata-kata menunjukkan keberanian bagai seekor singa. (Penyusun, 2010).

Begitulah sastra agama menyebutkan tugas dan kwajiban seorang pemimpin dan melaksanakan kepemimpinannya. Disamping itu seorang pemimpin juga dituntut memiliki intelejensi, yaitu mempunyai kemampuan mengobservasi situasi,karakter, adalah sifat-sifat keperibadian yang berhubungan dengan nilai-nilai kesungguhan, kejujuran dan kepercayaan, kesiap-siagaan, yaitu selalu awas dan waspada terhadap kemungkinan yang bisa terjadi,kesetiaan, adalah merupakan kode etik dari sifat jujur dan setia bagi umat hindu. Yang terpenting bagi seorang pemimpin adalah bagaimana yang bersangkutan dapat dengan cepat mengantisipasi situasi,mempunyai naluri dan insting yang kuat untuk mengatasi keadaan dalam situasi apapun. Jika semua terpenuhi maka tujuan akhir yang ingin dicapai bagi kelompok tertentu atau organisasi akan dapat tercapai dengan baik. Sesungguhnya setiap orang adalah pemimpin, paling tidak pemimpin bagi dirinya sendiri. Di dalam penelitian ini kepemimpinan adalah kemampuan seseorang untuk menguasai atau mempengaruhi sekelompok orang atau masyarakat yang satu sama lain mempunyai perbedaan berpikir untuk mencapai suatu tujuan yang diputuskan secara bersama. Seorang pemimpin harus mempunyai jiwa yang adil. harus mampu menarik perhatian yang positif dari masyarakat yang dipimpinnya. Seorang pemimpin harus mempunyai daya kreatif yang benar yang sesuai dengan dharma guna memimpin, daya kreatif yang luhur untuk memajukan kepentingan masyarkatnya. Seorang pemimpin harus mampu mengontrol bawahannya dan sekaligus memperbaiki hal-hal yang dipaandang kurang baik untuk menjadi lebih baik. Pemimpin harus memiliki moral yang baik dan luhur yang dapat dipedomani oleh bawahannya dan masyarakat yang dimpinnya.

Dalam Lontar Swargarohana Parwa nilai kepemimpinan juga tertuang dari penggalan cerita ketika Yudistira mencapai puncak gunung Himalaya dan dijemput untuk mencapai surga oleh Dewa Indra. Dalam perjalanannya dia ditemani oleh seekor anjing yang sangat setia. Dia menolak masuk surga jika disuruh untuk meninggalkan anjingnya sendirian. Si anjing menampakkan dirinya yang sebenarnya adalah Dewa Dharma. Tindakan yang dilakukan oleh Yudistira merupakan tindakan yang mengandung nilai kepemimpinan, karena seorang 
pemimpin harus dapat membuat keputusan yang cepat dan tepat walaupun harus mengorbankan dirinya sendiri.

Nilai kepemimpinan juga tertuang dari penggalan cerita ketika Yudistira lebih memilih berkumpul dengan saudara-saudaranya dan istrinya walaupun di neraka sekalipun. Yudistira mendekati saudara-saudara dan istrinya untuk ikut merasakan panasnya api neraka. Seketika keadaan berubah neraka yang ditempati oleh Pandawa dan Drupadi berubah menjadi surga. Dengan demikian dapat dipaparkan bahwa Yudistira telah mengamalkan nilai kepemimpinan, yang bertujuan untuk mencapai suatu keharmonisan di dalam melakukan suatu hal yang tidak bisa dilakukan dengan sendiri.

Berdasarkan beberapa kejadian-kejadian yang terdapat dari Lontar Swargarohana Parwa tersebut dapat dijelaskan bahwa cerita ini mengandumg nilai kepemimpinan. Sudah jelas dipaparkan bahwa nilai kepemimpinan dari cerita ini berarti suatu proses mempengaruhi atau menguasai sekelompok manusia yang berbeda pola pikir agar mencapai satu pemikiran yang hasilnya akan didapatkan sesuai dengan tujuan yang diinginkan bersama.

\section{Nilai Ksatria}

Ksatria adalah suatu sikap mental dan prilaku setiap orang berupa kegagahan beranian atau pantang mudur serta tidak mengenal menyerah atau mengalah dalam suatu perjuanagan untuk menegakan kebenaran, kejujuran dan keadilan demi untuk kemanusiaan dan kebahagiaan dunia. Ini berarti bahwa seseorang yang berjiwa ksatria dan sekaligus berjiwa pejuang. Dan sudah merupakan hukum bahwa setiap perjuangan memerlukan pengorbanan, baik harta benda maupun jiwa raga, tergantung dari sifat dan bentuk serta berat ringannya perjuangan itu sendiri, karena alam dengan segenap isinya ini diciptakan Tuhan melalui maha yadnyanya (pengorbanan suci dari dirinya sendiri). Sehubungan dengan itu setiap orang yang berjiwa ksatria didalam perjuangan menegakan kejujuran, kebenaran dan keadilan dituntut kesiapan untuk rela dan ikhlas berkoban dalam bentuk apapun, dimana dan kapan saja, tanpa mengharapkan balas jasa dan imbalan apapun. Setiap orang yang berjiwa ksatria didalam upayana memperjuangkan tegak kebenaran, kejujuran dan keadilan itu seyakin - yakinnya.

Didalam sikap mental dari prilaku ksatria berupa pantang mundur terkadang adanya rasa kesetiaan. Kesetiaan itu dapat ditunjukkan kepada berupa obyek. Seperti kesetiaan kepada agama juga kepada keluarga. Atas dasar kesetiaan itulah seseorang pantang mundur untuk memperjuangkan negaranya, agamanya, juga keluarganya. Ini berarti bahwa seseorang yang berjiwa ksatria didalam memperjuangkan sesuatu berdasarkan kejujuran, kebenaran, keadilan harus tahan dan tabah dalam menerimanya serta ulet dalam pelaksanaanya. 
Sesuai dengan pokok permasalah yang akan dibahas pada sub ini yaitu nilai pendidikan ksatria yang terdapat dalam Lontar Swargarohana Parwa terkait akan dikemukakan adanya nilai kstatria tersebut. Nilai ksatria itu dapat dilihat ketika Yudistira melawati banyak kejadiankejadian saat perjalan menuju ke sorga, sesampainya di sorga alangkah bingungnya Yudistira karena yang ditemui bukanlah sanak keluarganya melainkan Duryodana dan para Korawa serta Sekuni. Yudistira memutuskan dengan tegas akan mencari sanak keluarganya dimanapun berada walaupun Yudistira di minta agar tetap tinggal di sorga oleh Dewa Indra. Yudistira menolak dengan gagah berani dan tegas.

Berdasarkan uraian di atas maka nilai pendidikan ksatria dalam Lontar Swargarohana Parwa dalah suatu usaha untuk membangkitkan rasa kegagah beranian untuk pantang mundur dalam suatu pertempuran demi sebuah pengorbanan yang tulus iklas. Setiap ksatria dituntut kesiapannya untuk rela dan ikhlas berkorban dalam bentuk apapun, baik korban harta maupun korban jiwa.

\section{Nilai Ajaran Satya}

Ajaran satya adalah ajaran yang mengutamakan kesetiaan atau ketaatan, karena kesetiaan itu ceminan dari kepribadian seseorang. Orang yang tidak memahami dan tidak melaksanakan ajaran satya, maka orang itu tidak bisa dipercaya. Kesetiaan dalam Hindu merupakan sebuah ajaran agama yang wajib diamalkan. Kesetiaan di kelompokkan menjadi lima jenis yang lebih sering disebut dengan Panca Satya. Panca artinya lima dan satya artinya setia atau kesetiaan, jadi Panca Satya artinya lima unsur kesetiaan yang ada dalam diri manusia dan harus diamalkan dalam kehidupan sehari-hari. Kesetiaan dalam hidup merupakan hal yang sangat penting karena dengan kesetiaan kita bisa memperoleh sebuah kepercayaan yang mungkin tidak semua orang memilikinya. Kesetiaan itu muuncul bukan dari orang lain kesetiaan timbul dari diri sendiri jadi bagaimana caranya untuk memupuk kesetian itu.

Dalam Hindu, Panca Satya di bagi menjadi lima bagian yaitu : (1) Satya Semaya yang artinya adalah kesetian dengan janji yang pernah diucapkan dengan diri sendiri dan orang lain, sehingga dalam kehidupan tidak merasa beban dengan bayang-bayang janji yang pernah diucapkan. (2) Satya Herdaya adalah kesetiaan pada diri sendiri dan pada kata hati. Kadang manusia sering lupa apa yang ada dalam kata hatinya dan terkadang mengabaikan bisikan hati yang paling dalam. (3) Satya Mitra adalah kesetiaan terhadap teman. Dengan adanya teman manusia bisa sedikit berbagi segala suka duka, kelu kesah. (4) Satya Wacana adalah merupakan kesetiaan terhadap setiap tutur kata yang telah diucapkan. Artinya bertanggung jawab dengan perkataan yang telah dikeluarkan dari mulut. (5) Satya Laksana adalah kesetiaan terhadap 
setiap pelaksanaan atau perbuatan. Setiap manusia harus setia pada apa yang telah dilakukan atau diperbuat. Adapun perbuatan-perbuatan yang pernah di lakukan dan harus setia serta berani untuk mengakuinya juga bertanggungjawab akan akibat yang di timbulkan. Ingat ada sebab ada akibat.

Dalam Lontar Swargarohana Parwa terdapat ajaran Panca Satya yang terkandung di dalamnya. Mengenai bagian ajaran Satya Mitra yaitu ketika Yudistira di minta untuk tinggal di surga oleh Dewa Indra, dia tidak mau karena di surga tidak ada saudara-saudaranya dan istrinya, melainkan Duryodana dan saudara-saudanya, karena begitu keras kemauan Yudistira di antarlah dia menuju ke tempat saudara-saudaranya dan istrinya. Dia termenung dan berfikir apa dosa saudara-saudaranya dan istrinya hingga berada di api neraka ini, tanpa berfikir panjang akhirnya Yudistira mendekati saudara-saudaranya dan istrinya seketika keadaan berbalik menjadi sangat indah sedangkan di tempat Duryodana dan saudara-saudaranya berubah menjadi siksa neraka. Datanglah Dewa Indra dan Dewa Dharma bersabda orang yang lebih banyak dosanya ketimbang kebajikannya akan menikmati surga terlebih dahulu, baru kemudian dijebloskan ke neraka. Sebaliknya orang yamg lebih banyak berbuat kebajikannya dari pada dosanya akan diberikan siksa neraka terlebih dahulu sebelum diberikan kenikmatan sorga. Yudistira karena dia sangat memuja keagungan Dewa Dharma. Saelain itu juga Yudistira juga selalu mengupayakan Satya Semaya yaitu setia dengan janji-janji yang pernah beliau ucapkan dengan Catur Pandawa serta istrinya, bahwa Yudistira sudah pasti tidak menginginkan perpisahan dan kesenangan dengan dirinya saja, namun setiap suka duka yang dirasakan dilalui bersama-sama.

Berdasarkan penggalan Lontar Swargarohana Parwa juga terdapat ajaran Satya Herdaya yaitu ketika Yudistira tidak mau tinggal di surga, melainkan dengan tegas memilih mencari saudara-saudara dan istrinya, itu membuktikan bahwa Yudistira mengamalkan ajaran Satya Herdaya. Selanjutnya ajaran Satya Wacana juga terpaparkan di dalam penggalan cerita Swargarohana Parwa ini. Ajaran Satya Wacana merupakan kesetiaan terhadap setiap tutur kata yang telah diucapkan. Artinya bertanggung jawab dengan perkataan yang telah dikeluarkan dari mulut. Dalam cerita ini yang menganut ajaran Satya Wacana adalah ketika Yudistira yang setia terhadap setiap kata-katanya. Dalam cerita ini Yudistira berkata dia tidak akan menikmati surga tanpa saudara-saudara dan istrinya, sehingga dia mencari saudarasaudara dan istrinya. Berarti Yudistira sudah menjalankan ajaran Satya Wacana.

Selanjutnya ajaran Satya Laksana. Ajaran Satya Laksana terlihat dimana Yudistira dan saudara-saudara serta istrinya sewaktu masih hidup pernah melakukan kesalahan sehingga 
harus mendapatkan hukuman. Yudistira pernah berbohong pada Guru Drona, Bima terlalu menonjolkan sifat Lobanya, Arjuna terlalu bangga dengan kemahirannya, Nakula sangat membanggakan ketampananya, Sahadewa begitu membanggakan kecerdasannya serta Drupadi lebih mencintai Arjuna dari pada suami-suami yang lainnya.

Semua hal yang terjadi di dalam cerita ini merupakan suatu hal yang terjadi karena kesetiaan terhadap Tuhan, kesetiaan terhadap diri sendiri atau kata hati, kesetiaan terhadap teman, kesetiaan terhadap perkataan dan kesetiaan terhadap segala perbuatan. Meskipun di dalam insiden-insiden yang terjadi pada cerita tersebut tidak semuanya melangkah pada hal yang baik, namun setidaknya tokoh dalam cerita tersebut telah mengamalkan ajaran Satya. Semuanya itu tertuang pada ajaran Panca Satya yaitu Satya Semaya, Satya Herdaya, Satya Mitra, Satya Wacana dan Satya Laksana yang sudah dijelaskan dari setiap bagian-bagian yang terkandung di dalam Lontar Swargarohana Parwa.

\section{Simpulan}

Nilai-nilai pendidikan agama Hindu yang terkandung dalam Lontar Swargarohana Parwa adalah a). Nilai Pendidikan Sosial yaitu kebiasaan untuk saling berinteraksi. Nilai sosial yang terdapat dari Lontar Swargarohana Parwa ini adalah ketika Yudistira merasa tidak dapat hidup sendiri tanpa ditemani oleh sanak keluarganya. b). Nilai Yadnya artinya perbuatan yang dilaksanakan secara tulus ikhlas. Dalam cerita ini mengandung Nilai Yadnya ketika Yudistira menceburkan dirinya kedalam sungai Witarini yang airnya mendidih demi dapat berkumpul dengan saudara-saudara serta istrinya. c). Nilai Moral yaitu kebiasaan bertingkah laku yang baik. Dalam Lontar Swargarohana Parwa banyak sekali terdapat pesan-pesan moral yang harus diterapkan dalam kehidupan sebagai manusia. Nilai Moral dalam Lontar Swargarohana Parwa terlihat dalam penggalan cerita ketika Yudistira menceburkan diri ke dalam kobaran api neraka untuk dapat bertemu dengan saudara-saudaranya serta istri dan sekutu Pandawa. d). Nilai Kepemimpinan yang berarti kemampuan untuk mempengaruhi suatu kelompok menuju tercapainya tujuan-tujuan. Nilai kepemimpinan yang terkandung dalam cerita ini ketika Yudistira mencapai puncak gunung Himalaya dan dijemput untuk mencapai surga oleh Dewa Indra. Dalam perjalanannya dia ditemani oleh seekor anjing yang sangat setia. Dia menolak masuk surga jika disuruh untuk meninggalkan anjingnya sendirian . e). Nilai Ksatria yaitu sikap kegagah beranian. Penggalan cerita ketika Yudistira memutuskan dengan tegas akan mencari sanak keluarganya dimanapun berada walaupun Yudistira di minta agar tetap tinggal di surga oleh Dewa Indra. Yudistira menolak dengan gagah berani dan tegas yang menganut nilai 
Ksatria. f). Nilai Satya dalam Lontar Swargarohana Parwa merupakan manifestasi dari kemurnian jiwa Yudistira yang selalu mentaati kesetiaan dan tauladan bagi Pandawa dan istrinya. Nilai Panca Satya selalu terselipkan dalam setiap insiden-insiden yang terjadi antar setiap tokoh. Seperti ketika Yudistira mengupayakan Satya Semaya yaitu setia dengan janjijanji yang pernah beliau ucapkan dengan Catur Pandawa serta istrinya, bahwa Yudistira sudah pasti tidak menginginkan perpisahan dan kesenangan dengan dirinya saja, namun setiap suka duka yang dirasakan dilalui bersama-sama.Keenam nilai tersebut diterapkan dalam Lontar Swargarohana Parwa. Nilai nilai tersebut merupakan cerminan perilaku atau tingkah laku dalam setiap tokoh di cerita tersebut yang berguna bagi kehidupan manusia dalam bermasyarakat.

\section{Daftar Pustaka}

Darmadi, H. (2007). Dasar Konsep Pendidikan Moral; Landasan Konsep Dasar dan Implementasi . Bandung: CV. Alfabeta.

Hasibuan, M. (2003). Manajemen Dasar Pengertian dan Masalah. Jakarta: PT. Toko Gunung Agung.

Kebudayaan, D. P. (2001). Kamus Besar Bahasa Indonesia Edisi Kedua. Jakarta: Balai Pustaka.

Muhibbin, S. (1995). Psikologi Pendidikan Suatu Pendekatan Baru. Bandung: PT. Remaja Rosdakarya.

Penyusun, T. (2010). Etika Hindu. Surabaya: Paramitha.

Poespoprodjo, W. (1998). Filsafat Moral. Bandung: Pustaka Grafika.

Robbin, \& Coulter. (1999). Manajemen Edisi Keenam. Jakarta: PT. Prenhallindo.

Sutrisno, S. (1997). Hikayat Hang Tuah Analisis Struktur dan Fungsi . Yogyakarta: Gadjah Mada University Press.

Usman, H., \& Akbar, S. P. (1996). Metodologi Penelitian Sosial. Jakarta: Bumi Aksara. 